\title{
Omar T. Woodard
}

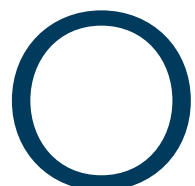

mar T. Woodard currently serves as the Executive Director of the Greenlight Fund Philadelphia. He previously worked as Policy Director for Pennsylvania State Senator Anthony Hardy Williams, Principal at Venture Philanthropy Partners, a healthcare consultant at The Advisory Board, and as a lobbyist for The Whitaker Group. Mr. Woodard is also an adjunct professor at Temple University's Fox School of Business. He possesses extensive experience as a board member of various education and professional organizations. Mr. Woodard holds two degrees from George Washington University: a Bachelor of Arts in International Affairs and a Master of Public Administration. 
Policy Perspectives: You currently serve as Executive Director for the Greenlight Fund Philadelphia. Can you tell us a little bit about the Greenlight Fund and the type of work that you do?

Omar Woodard: The Greenlight Fund is a nonprofit focused on ending poverty in the cities we're in. We do that by matching the needs that low-income communities with the best programs in the country that meet those needs. The first thing we do is engage in community conversations to understand where the gaps are in the nonprofit space that focus on ending poverty in our cities. The next thing we do is identify the best social entrepreneurs in the country that are addressing really important issues around poverty. And finally, we make investments in those organizations to bring them to our cities and help them stand up in scale for long-term success. We launched in Boston about 13 years ago, and now we are in seven cities across the country including Philadelphia, Charlotte, the Bay Area, Cincinnati, Detroit and soon to open in Kansas City. We're a nonprofit like everyone else, a 501(c)(3) public charity. We do operate somewhat as a grant-maker, but that's not how define ourselves. We define ourselves as a community tool to support the needs and wants of low-income communities to celebrate economic mobility in their neighborhood.

PP: That's really interesting. When we first researched the Greenlight Fund, we saw it described as a kind of nonprofit venture capital fund.

OW: That's how we structure ourselves. We're not a foundation that has an endowment. We raise all of the money that we invest. And the venture capital piece is that we are structured as a venture philanthropy firm which has three components to it. One, no endowment, two, an approach of investments rather than grants, which are typically one year or two years, and three, we are investments which means multi-year as well as mutually beneficial partnerships. So, we are also deeply, deeply invested in the success of the organizations that we invest in. If they don't do well, we don't do well. Whereas foundations, it's a learning opportunity. For us, we're doing as much as we can to make sure we're making the right match for low-income communities in Philadelphia, or Oakland, or Cincinnati. So, for us, we consider ourselves a non-profit venture capital; we're raising the dollars, identifying gaps in the market, and filling those gaps with the best service we can find with a high-quality entrepreneur running it.

PP: You've stated in previous interviews that your main goal is to end deep poverty in North Philadelphia. Where do you think you or the organizations you fund have been able to make progress toward that goal? What are some of the main obstacles that still need to be overcome or big changes that still need to happen?

OW: The issue of deep poverty is a fascinating one. We know that poverty is set up as a family of four making $\$ 25,000$ a year. Deep poverty is making half of that. So, that is a family of four living on $\$ 12,000$ a year, which is about $\$ 250$ a week. If you live in deep poverty, the issue from getting you from deep poverty to poverty is largely a function of money, and the amount of money you're able to generate via jobs, or public benefits, or otherwise. From that point, we made an investment in Single Stop, which is an organization that has a propriety benefits access tool. What that means is it screens individuals for the public benefits (federal, state, and local) which they're eligible for. And then with the case management support function, helps them actually get those benefits. A good example of that would be the Earned Income Tax Credit (EITC). In Philadelphia alone, Philadelphians who qualify for EITC don't apply for it. So, they leave anywhere between $\$ 80$ million and 
$\$ 100$ million on the table that belongs to them. From our perspective, we wanted to bring Single Stop to the city of Philadelphia because it has the largest number of individuals in poverty and deep poverty of any big city in the country. Therefore, if we can connect those individuals with the money they're eligible for, we can find ways to stabilize their financial and social situation. Single stop partnered with the Community College of Philadelphia (CCP). The reason was so that we could solve two problems in one. Over six years, the CCP only graduated 22 percent of the students who started there (those being are firsttime low-income students). So, if we could target first-time low-income students who are entering community college, and connect them to benefits and services we know they are eligible for, we can stabilize their situation and improve their educational outcomes by improving their persistence and completion of community college. Over the last five years of this investment, they've screened about 6000 students and have been able to ascertain about $\$ 18$ million in cash and non-cash benefits to those students. What that means is that they were able to get a young mother who did not have WIC (The Special Supplemental Nutrition Program for Women, Infants, and Children), were able to get WIC, or a young father who didn't have SNAP (Supplemental Nutrition Assistance Program), and now he has SNAP, or a young women with no children at all but who has never done taxes before, free tax preparation, or a young mother of two who didn't have quality healthcare and was able to sign them up for the Affordable Care Act. These are the things that Single Stop does. So, when it comes to poverty, I think we need to focus on ending it rather than of reducing it. The way you end it is to get to the fundamental issues which are: one, people are poor for lots of reasons but primarily because they don't make enough money or two, the space or the place that they live in keeps them poor. It isolates them from things that other people have, whether its educational amenities, high-speed internet, connection to other social capital, or parks and rec centers. Where people live can isolate them from things that will help them to be successful. Long story short, our focus over the next several years for Greenlight Philadelphia is to accelerate economic mobility by investing in children and families, and neighborhoods and communities. In addition, we want to tackle public systems that perpetuate poverty like public housing, public health, child welfare systems, and the public education system. By going at it in those three ways, we think that we can measurably make a dent on the issues of poverty. It's not just about reducing the number of people who are poor, but also moving and keeping them out of poverty. So, we had to think about it very holistically. That's been our approach over the last several years.

PP: How many people in the Philadelphia area live in what is defined as deep poverty? OW: There are 400,000 individuals that live in households that are considered poor. There are 190,000 individuals that live in households considered to be in deep poverty.

\section{PP: You did your undergrad at GW and were student body president, and you were then awarded a Presidential Administrative Fellowship (PAF) at GW to pursue a master's degree. What made you decide to pursue an MPA specifically?}

OW: My senior year when I was student body president, I spent a lot of time working with the board of trustees. I spent a lot of time managing the million-dollar entity that was the student association. I hired staff, had a payroll, managed budget, I looked at P \& L's (profit and loss statements), and I had to lead as well as manage. So, having that early experience as a 20 -yearold gave me insight into the kind of work I wanted to do moving forward in my career. One 
of it was managing a nonprofit. I just kind of knew that this type of work is what I eventually wanted to do based on the experience I had running the student association. The other piece was more so around nonprofit governance. I learned so much being involved with the board of trustees at GW as the student government president largely because I got to understand how at large universities or big nonprofits the importance of the role of the board in achieving good outcomes. Those outcomes could be direct service outcomes like nonprofits, but it's also managing the institution's strategic direction. This is making sure that the board knows important is to hire the right people, to hire people that will hire the right people, and having the sense to oversee that and manage that. I had an up close and personal view of how an organization that had $\$ 800$ million in revenue and a $\$ 1.3$ billion endowment did its work every day, and that fascinated me. So, the MPA to me was a no-brainer. I considered law school, but I had a conversation with Steve Trachtenberg during my senior year about that. I asked him should I go to law school or get my MPA because he had both. I thought maybe it made sense to do one or the other. He said "If you're not going to practice law, don't go to law school. If you want to manage organizations and serve on boards, you probably want to do the MPA." That advice led me to attend the school of public policy and public administration named after him.

\section{PP: Can you talk a little bit about where and how you've been able to apply the knowledge, skills, and/or experiences from your time at GW to your professional life? What aspects of the MPA program have you found most valuable?}

OW: That's a good question. I still have all of my syllabi and papers from every class. I started with Jed Key. However, the core of my classes (because I concentrated in nonprofit management), were with Michael Worth. Once when I was working at Venture Philanthropy Partners in DC, low and behold, in a meeting, Michael Worth walks in. I said, "Professor Worth, what are you are doing here?!" He says, "Well, I'm a consultant and I work with development strategy and boards." It reminded me of the fact that at GW in particular, the people I learned from did this work everyday; it was not abstract or academic for them. They are practitioners of this work. That gave me a ton of excitement about the work I would be doing, and it helped me think about how useful it is to have learned from these really great folks. The one area where I think I have learned and put most things into practice has been on the board/nonprofit governance side. The work I did managing and governing nonprofit boards and those classes as well as understanding the trends of nonprofit governance was incredibly fascinating for me. I took a class with Sara Melendez (I believe she was formally the president of Independent Sector) who helped us walk through a number of case studies about the nonprofit sector. From her case studies, I learned how SarbanesOxley impacted nonprofit operations at the board level, in particular. As someone who is a funder, who looks at organizations and tries to ascertain whether to invest in them, I always go back to Sara Melendez' and to Mike Worth's classes. What I've learned about the importance of understanding the audit function of a board, the importance of term limits and board share, all of these things you learn in school and think "Ah, that's interesting," is that they matter. A lot of the things I learned, wrote papers on, read, and listened to in class are actually things I have to decide on, like whether I'm going to give $\$ 600,000$ or $\$ 1.4$ million to an organization based on the things I learned right there in the classroom. I would say that there nothing academic about it. Everything I learned through the MPA process, particularly about nonprofit management and governance, are things that I use 
every single day. Number one, that's just good news. Number two, it lets you know how timely and rich their academic content was and how real they made it that I can so quickly turn it into something meaningful here in Philadelphia and when I was in DC. To answer your question specifically, I would say that the knowledge and understanding of nonprofit board governance and the future of nonprofit governance and its role in a high-performing nonprofit sector helped me become a better funder; someone who could really make decision on whether an organization was worth investing in or not.

\section{PP: What were you doing while you were getting your MPA and working at GW for the PAF? What were you doing at the same time and how did that influence the kind of classes you were taking or what you wanted to do afterwards?}

OW: I was working 35 hours per week and going to school full-time. The first job I had was to stand up a brand-new office in the university called the Office of Customer Service Initiative. The idea was to think about to treat parents and student with more dignity and respect than we did at the time, particularly in the areas of financial services and parent services. The question was, "How do we create a one-stop shop and a visible brand that lets students and parents know that there are standards we hold ourselves accountable to ensure their satisfaction from a business operations perspective?" So, we ended up designing and implementing Colonial Central in the basement of the Marvin Center. Before then, the registrar was in the Academic Center, financial aid was on the third floor of Rice, and student account was on the second floor. So, you had to bounce around from place to place. I learned ton about what it took to start something from scratch and build something from nothing. It was very important for my nonprofit experience because what I do at Greenlight is help organization launch new in Philadelphia, every year. So, my first year out of college was doing that in a university setting. The second year, I worked as an outreach coordination for the Office of Corporate Foundation Relations at the university. I learned a ton about how to articulate a value proposition for research and grants to both corporate and philanthropic funders. That gave me another point of view on how to engage with nonprofits, philanthropy, and foundations. It also allowed me to see what corporate foundations find valuable, specifically the connection to their brand and their assets, and figure out how to get them interest and excited about the work. So that's what I did during the two years of the MPA. It ducktailed incredibly well with the work I was doing in class and the work I was doing outside of it. It was a good nexus.

\section{PP: It sounds too good to be true!}

OW: I did have a plan. I knew that when I got the MPA I wasn't going to go straight into nonprofit or philanthropy work. But I knew that at some point I would. After I graduated, I went back to what I focused on in undergrad which was international economics. So, I specialized in US-Africa trade and investment and represented US governments that did business in Africa and African heads of state that wanted to do more business in Africa. As I started moving through my career, I pivoted back to the grad school work. This is how I got into venture philanthropy work, board stuff, joining a ton of nonprofit boards, and getting involved in the Greenlight Fund work. It does seem too good to be true, but after doing all that work, I went back to what I studied in undergrad in the first place, knowing that I would come back to the nonprofit stuff later. 
PP: Before you came to the Greenlight Fund, you also worked in the private sector as a lobbyist, you worked for the Advisory Board, and for several political campaigns. You've also explored running for office in the past. Is running for office something you see yourself doing in the future?

OW: Yeah, definitely. For me, being involved in government is all about being in the position to solve problems at the scale of the challenge. At Greenlight, I can work on issues that help 1000 families in a city of 1.6 million. I can help 2,000-3,000 over time, and maybe after 5 years get to a portfolio of organizations that serve 10,000 individuals a year in a city of 1.6 million. But if you're really interested in grappling with the sheer scale of the problem, which is the number of people living in deep poverty in the city of Philadelphia, well its 190,000. So how do I engage myself in developing solutions for the 190,000 rather than the 1,000 or 10,000 ? Government is the best place to do that. That's what attracts me to that space. Certainly, in the future, an opportunity may be presented. But in the near term, I'm going to be happy with the 1,000 and 2,000 families and doing what we can with the resources we have.

PP: It's nice to have an optimistic picture of government as a force for good and for helping people. That's an idea of government that is sort of rapidly disappearing. Its nice to know folks still think like that.

OW: It's the only structure we have. It's the only institution humans have developed that can care about the full development of human potential. There's no other institution that cares or has the incentive to care about the development of human potential. We can stay that there's pharmaceutical companies or some health care companies that really care, but there's a dollar sign attached to that. Government is the one area where we say this is a public good, this is good for all. It doesn't matter if it runs at a deficit. We're going to spread that deficit and risk across the entirety of our population because it's that important. I think it's not just being optimistic; it's the only thing that we created the can solve challenges at the scale that we have them. Nothing else exists that can do that.

PP: And finally, what advice would you give to current students at Trachtenberg who are thinking about the next step in their careers? Are there things you wish you'd known or that you'd done when you were working on completing your degree?

OW: I wish I'd gone to class more! I did well, but it's tough when you work full-time and go to school full-time. I should have spent more time with Kathy in Program Evaluation class for sure. For people going straight from undergrad into a masters like I did, it helped me build a network of peers and not-so peers that gave me insight into what my future could be. There were a ton of people who were mid-career and came back to get an MPA. So, I got a sense of what their trajectory was and what the MPA could add. It's not just being a consultant or working in government or a nonprofit. There's a bunch of people who think that because they have the MPA they need to take that and go into consulting or go into government or nonprofit., But there's just so many other career trajectories. My advice would be to think more about what an MPA can do for you The MPA of Marie Johns, who was the Marketing President of Verizon in DC, she had an MPA. I think about people like Steve Trachtenberg who did not have a PhD; he had an MPA and was able to do a range of interesting things. I mean, was working in trade and investment as a lobbyist, working on Capitol Hill, and with nonprofits. There's just such an array of opportunities available to 
folks that have an MPA. I would just encourage them think as broadly as possible about the ambitions of their career and know that the MPA doesn't do anything to constrain any of those options. In fact, it may give them a better ability to articulate why their value is much better than others without an MPA. That's the biggest piece of advice I would give them. 